\title{
HUBUNGAN GENOTIPE rs 1042713 (Arg16Gly) DENGAN EFEKTIVITAS $\beta 2$-AGONIS PADA PENDERITA ASMA
}

\author{
Sri Haryanti ${ }^{1 *}$, Zullies Ikawati ${ }^{2)}$, Mustofa $^{3)}$, Tri Murti Andayani ${ }^{2)}$ \\ ${ }^{I}$ Stifar Yaphar, Semarang, Indonesia \\ ${ }^{2}$ Fakultas Farmasi UGM, Yogyakarta, Indonesia \\ ${ }^{3}$ Fakultas Kedokteran UGM, Yogyakarta, Indonesia. \\ "Email: yantif2_stifar@yahoo.com
}

\section{INTISARI}

Untuk menghasilkan efek, obat agonis $\beta 2$ akan berikatan dengan reseptor ADRB2. Efek agonis $\beta 2$ menunjukkan variasi antar individu yang disebabkan adanya polimorfisme gen penyandi. Terdapat 80 polimorfisme ADRB2, diantaranya Arg16Gly yang berada pada asam amino 16. Genotipe ADRB2 bawaan dinamakan wildtype, sedangkan jika mengalami mutasi dinamakan mutant. Tujuan penelitian ini adalah untuk mengetahui adakah hubungan antara genotipe rs 1042713 (Arg16Gly) dengan efektivitas obat $\beta 2$-Agonis pada penderita asma. Penelitian ini adalah penelitian observasional dengan rancangan cross sectional dan pengambilan data secara prospektif. Pemeriksaan adanya polimorfisme gen dan penilaian efektivitas melalui kuesioner dilakukan setelah pasien asma menandatangani informed consent. Kriteria inklusi adalah pasien asma, dewasa, kedua orang tuanya berasal dari suku-suku di Indonesia, dan menggunakan inhaler $\beta 2$-agonis atau kombinasi $\beta 2$ agonis dan kortikosteroid untuk pemeliharaan. Sebanyak 101 pasien asma yang memenuhi kriteria inklusi dipilah berdasar tipe genom dengan pemeriksaan farmakogenomik dan efektivitas $\beta$-agonis dalam bentuk sediaan inhaler menggunakan kuesioner Asthma Control Test (ACT). Hasil uji statistik dengan chi square untuk mengetahui hubungan tipe genom dan kontrol asma diperoleh nilai $\mathrm{p} 0,131$. Perbandingan efektivitas tipe genom wildtype lebih efektif $1,887 \mathrm{x}$ dibanding mutant dan heterozygote lebih efektif 1,667x dibanding mutant. Tidak ada hubungan bermakna antara genotipe rs 1042713 (Arg16Gly) dengan efektivitas, tetapi kemungkinan secara klinis berbeda.

Kata kunci: Asma, $\beta 2$-agonis, ADRB2, genotipe, efektivitas.

\begin{abstract}
To produce an effect, the agonist drug $\beta 2$ will bind to the ADRB2 receptor. The effect of agonist $\beta 2$ shows variation between individuals due to the presence of encoding gene polymorphisms. There are 80 ADRB2 polymorphisms, including Arg16Gly in amino acids 16. The innate ADRB2 genotype is called wildtype, whereas mutated ones is called mutant. The purpose of this study was to determine whether there was a relationship between genotype rs 1042713 (Arg16Gly) and the effectiveness of $\beta 2$-agonist drugs in asthma sufferers. This study was an observational study with a cross sectional design and prospective data collection. Examination of the presence of gene polymorphisms and assessment of effe A total of 101 asthma patients who met the inclusion criteria were sorted by genome type by pharmacogenomic examination uses the Asthma Control Test (ACT) questionnaire. The results of the statistical test with chi square to determine the relationship of genome type and asthma control obtained $p$ value 0.131 . The comparison of the effectiveness of the wildtype genome is more effective than the mutant of 1.887x, and heterozygote is more effective 1,667x greater than the mutant. There is no significant relation between genotypes rs 1042713 (Arg16Gly) with effectiveness, but the possibility of clinical effectiveness is different.
\end{abstract}


Keywords: Asthma, $\beta 2$-agonist, ADRB2, genotype, effectiveness.

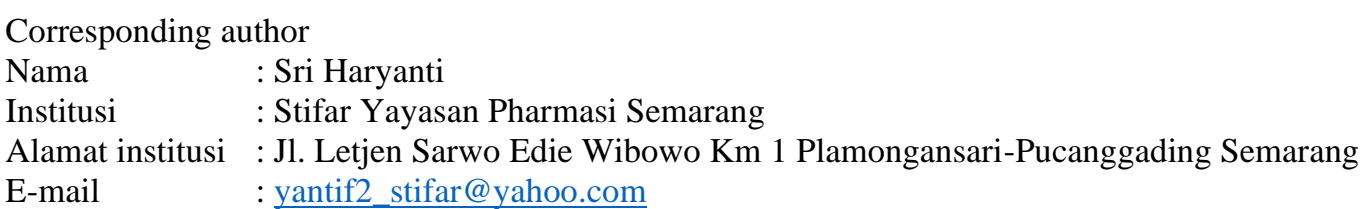

\section{PENDAHULUAN}

Asma merupakan penyakit pada saluran pernafasan yang dapat terjadi pada anak maupun orang dewasa. Hasil riset kesehatan dasar tahun 2018 menunjukkan prevalensi asma sebesar 2,4\% Angka tersebut lebih besar dibanding DM $(2 \%$ ), kanker $(1,8 \% 00)$, dan jantung $(1,5 \%$ ) Kesehatan, 2018). Pengobatan asma dapat diklasifikasikan menjadi controllers atau relievers. Beberapa golongan obat dapat digunakan untuk mengatasi asma, diantaranya adalah untuk pengontrol inflamasi, agonis $\beta 2$. Untuk menghasilkan efek, obat agonis $\beta 2$ akan berikatan dengan reseptor ADRB2.

Beberapa faktor termasuk genetik akan mempengaruhi keberhasilan pengobatan (Hakim, 2012). Perubahan fungsi reseptor pada enzim target contohnya adrenergik reseptor $\beta 2$ (ADRB2) yang mempengaruhi agonis $\beta 2$ untuk asma (Trent dkk., 2013). Gen ADRB2 terletak pada kromosom 5q31-32 terkait dengan fenotipe asma, dilaporkan sangat polimorfik (Kobilka dkk., 1995; Postma dkk., 2005). Arg16Gly merupakan polimorfisme non synonimous yang banyak berkaitan dengan agonis $\beta 2$ (Green dkk, 1995). Arg16Gly berada pada asam amino 16, Arg dianggap wildtype (Hall, 2006; Litonjua dkk., 2010).

Kruketi dkk (2005) meneliti pengaruh polimorfisme ADRB2 dan respon penderita asma terhadap salbutamol memberikan hasil pasien dengan homozigot AA (Arg-16) memberikan respon lebih buruk dibanding pasien dengan homozigot GG (Gly-16). Israel dkk (2004) membandingkan peningkatan Peak Expiratory Flow Rate (PEFR) di pagi hari pada pasien dengan genotipe Arg/Arg dan Gly/Gly setelah pemberian salbutamol. Pada penggunaan salbutamol dengan dosis minimum, PEFR Arg/Arg mencapai 23L/menit, sedangkan Gly/Gly hanya 2 L/menit (Israel dkk, 2004).

Penelitian ini bertujuan untuk mengkaji hubungan antara genotipe rs 1042713 (Arg16Gly) dengan efektivitas $\beta 2$-Agonis pada penderita asma. Penelitian ini penting dilakukan sebagai dasar pemberian terapi asma controller.

\section{METODE PENELITIAN}

\section{Desain, Bahan dan Alat Penelitian}

Penelitian ini adalah penelitian observasional rancangan cross sectional dengan pengambilan data secara prospektif. Bahan yang digunakan untuk penelitian ini adalah sampel darah pasien asma untuk uji farmakogenetik. Pasien berasal dari 5 rumah sakit di Daerah Istimewa Yogyakarta dan 1 rumah sakit di Jawa Tengah, menandatangani informed consent dan telah melalui uji etik dari Fakultas Kedokteran UGM. Bahan lain yang digunakan dalam penelitian ini adalah data hasil pengisian kuesioner Asthma Control Test (ACT) oleh pasien. Alat yang digunakan adalah mesin PCR untuk uji isolasi DNA, sedangkan reagen yang digunakan kit "Promega", dan enzim NcoI untuk memotong hasil isolasi DNA. Alat lain yang digunakan untuk mendapatkan data efektivitas adalah kuesioner Asthma Control Test (ACT).

\section{Jalannya Penelitian}

Pemeriksaan gen dilakukan dengan pengambilan darah sebanyak $3 \mathrm{~mL}$ oleh petugas laboratorium klinik di rumah sakit tempat penderita berobat. Darah lengkap dimasukkan dalam tabung steril yang berisi antikoagulan EDTA. Selanjutnya disentrifugasi 3500 rpm selama 10 menit, dan bagian buffy coat digunakan untuk isolasi DNA. Pemeriksaan polimorfisme ditentukan dengan PCR-RFLP (Polymerase Chain Reaction - Restriction Fragment Length Polymorphism). Primer yang digunakan 5'- GCC TTC TTG CTG GCA CCC CAT -3' (foward) dan 5'- CAG ACG CTC 
GAA CTT GGC CAT G -3' (reverse) (Birbian dkk., 2012). Digesting (pemotongan) terhadap DNA hasil PCR (168 bp) menggunakan enzim Ncol, pada suhu $37^{\circ} \mathrm{C}$ selama 2 jam.

Pengukuran efektivitas menggunakan kuesioner Asthma Control Test (ACT), untuk mengetahui tingkat kontrol asma. Kuesioner ini terdiri dari lima pertanyaan untuk mengevaluasi asma dari penderita yang berusia di atas 12 tahun. Parameter yang dinilai adalah gangguan aktivitas harian akibat asma, frekuensi gejala asma, gejala malam, penggunaan obat pelega dan persepsi terhadap kontrol asma. Masing-masing pertanyaan mempunyai lima pilihan jawaban dengan skor 1 sampai 5. Selanjutnya hasil kuesioner ACT digunakan untuk mengelompokkan kondisi klinis pasien ke dalam kriteria terkontrol, skor $<19$ tidak terkontrol dan 20-24 terkontrol sebagian.

\section{Analisis Data}

Genotipe rs 1042713 (Arg16Gly) dilihat dari hasil elektroforesis dengan enzim Nco1, sehingga dapat ditentukan jenisnya wildtype, mutant, maupun heterozygote. Hasil pengukuran efektivitas dengan kuesioner Asthma Control Test (ACT) diperoleh skor tertentu untuk mengkategorikan derajat keparahan asma. Hubungan antara genotipe rs 1042713 (Arg16Gly) dengan efektivitas $\beta 2$-Agonis pada penderita asma dilakukan dengan program SPSS 23.

\section{HASIL DAN PEMBAHASAN}

Penelitian ini dilakukan untuk mengetahui hubungan antara genotipe rs 1042713 (Arg16Gly) dengan efektivitas $\beta 2$-Agonis pada penderita asma. Polimorfisme gen diketahui dengan pemeriksaan laboratorium terhadap sampel darah pasien, berupa isolasi DNA dilanjutkan uji varian gen dengan metode PCR-RFLP. Efektivitas diukur dengan menggunakan kuesioner Asthma Control Test (ACT). Skor yang diperoleh dari kuesioner menunjukkan kriteria kontrol asma.

Sebanyak 101 subjek penelitian yang memenuhi kriteria inklusi berasal dari 5 rumah sakit di Daerah Istimewa Yogyakarta dan 1 rumah sakit di Jawa Tengah. Karakteristik pasien dapat dilihat pada Tabel I.

Tabel I. Data karakteristik pasien berdasar jenis kelamin, usia, dan durasi asma.

\begin{tabular}{lcc}
\hline \multicolumn{1}{c}{ Variabel } & Banyaknya & $\begin{array}{c}\text { Persentase } \\
(\boldsymbol{\%})\end{array}$ \\
\hline Jenis kelamin & & \\
Pria & 41 & 40,59 \\
Wanita & 60 & 59,41 \\
\hline Usia (tahun) & & \\
$18-30$ & 7 & 6,93 \\
$31-40$ & 6 & 5,94 \\
$41-50$ & 27 & 26,73 \\
$51-60$ & 36 & 35,65 \\
$>60$ & 25 & 24,75 \\
\hline Durasi asma (tahun) & & \\
$1-5$ & 23 & 22,77 \\
$6-10$ & 20 & 19,80 \\
$11-15$ & 32 & 31,70 \\
$>15$ & 26 & 25,73
\end{tabular}

Pasien asma wanita lebih banyak (59\%) dibanding pria (41\%). Tingginya pasien asma wanita dibanding pria juga pernah dilaporkan oleh beberapa peneliti sebelumnya (Price dkk., 2015; Rahayu dan Hamdini., 2013; Yunitasari, 2013). Penelitian lain yang dilakukan oleh Marco dkk. (2000) 
menunjukkan pada usia > 15 tahun penderita asma wanita lebih banyak dibanding pria, tetapi pada usia 5-15 tahun prevalensi hampir sama. Kemungkinan penyebab tingginya prevalensi asma wanita dibanding pria yaitu ukuran paru dan bronkhi wanita lebih kecil dibanding pria, sehingga mempengaruhi sirkulasi udara pada sistem pernafasan (GINA, 2017; Marco dkk., 2000). Faktor lain yang mempengaruhi tingginya prevalensi asma pada wanita adalah pengaruh hormonal (Marco dkk., 2000). Tingginya kadar estrogen memicu reaksi inflamasi dan meningkatkan kadar substansi proinflamasi sehingga memperburuk asma (Lim dan Kobzik, 2008; Vrieze dkk., 2003).

Tabel I menunjukkan usia penderita asma terbanyak adalah pada usia 51-60 tahun (35,64\%). Hasil ini sebanding dengan penelitian Andayani dan Waladi (2014) yang melaporkan 83\% pasien asma di Indonesia berusia 18-60 tahun dan 17\% berusia > 60 tahun. Dari beberapa studi diketahui kekambuhan asma pasien anak-anak mulai menghilang di usia remaja tetapi akan muncul kembali seiring dengan bertambahnya usia. Disamping itu terjadi penurunan fungsi paru-paru dan peradangan jalan nafas seiring meningkatnya usia (Sihombing dkk., 2010). Berdasarkan lama menderita asma, diperoleh hasil 32 orang $(31,68 \%)$ telah menderita asma selama 11-15 tahun menempati urutan teratas, sedangkan urutan terbawah adalah pasien yang menderita asma lebih dari 20 tahun sebanyak 1 orang $(0,99 \%)$.

Efektivitas terapi ditandai dengan tingkat kontrol asma pasien, yaitu prediktor risiko ketidakstabilan asma dan eksaserbasi (GINA, 2017). Mengukur tingkat kontrol asma dilakukan dengan mengetahui gejala asma dalam 4 minggu terakhir. Dalam penelitian ini untuk mengetahui tingkat kontrol asma dilakukan dengan menggunakan kuesioner Asthma Control Test (ACT) yang dibagikan kepada penderita asma yang menjadi subjek penelitian. Ada 5 pertanyaan pada kuesioner ACT, setiap nomor pertanyaan dalam rentang skor 1-5, sehingga total skor minimal 5 dan maksimal 25. Hasil skor dapat dikategorikan menjadi 3, yaitu terkontrol penuh (skor 25), terkontrol sebagian (skor 20-24), dan tidak terkontrol (skor $\leq 19$ ). Hasil penelitian diperoleh skor rata-rata 17,24 pada laki-laki dan 16,63 pada wanita. Disimpulkan bahwa pada laki-laki maupun wanita skor rata-rata yang diperoleh $\leq 19$, sehingga berada pada kriteria asma tidak terkontrol. Selain dengan perhitungan skor rata-rata, data dapat diolah dengan cara mengelompokkan setiap data skor ke dalam kriteria terkontrol penuh, terkontrol sebagian, maupun tidak terkontrol (Haryanti dkk., 2016).

Pada Tabel II diperlihatkan banyaknya subjek laki-laki dan wanita berdasar kriteria kontrol asma, yaitu terkontrol sebagian dan tidak terkontrol, sedangkan yang masuk kriteria terkontrol penuh tidak ditemukan.

\section{Tabel II. Banyaknya laki-laki dan wanita berdasar kriteria kontrol asma}

\begin{tabular}{lcccccc}
\hline Kriteria kontrol asma & \multicolumn{2}{c}{ Laki-laki } & \multicolumn{2}{c}{ Wanita } & \multicolumn{2}{c}{ Total } \\
\hline & $\mathrm{n}$ & $\%$ & $\mathrm{n}$ & $\%$ & $\mathrm{n}$ & $\%$ \\
\hline Terkontrol sebagian & 10 & 9,90 & 16 & 15,85 & 26 & 25,75 \\
Tidak terkontrol & 31 & 30,69 & 44 & 43,56 & 75 & 74,25 \\
\hline
\end{tabular}

Tabel II menunjukkan persentase tidak terkontrol lebih besar dibanding terkontrol sebagian. Hasil penelitian ini sejalan dengan penelitian Price dkk. (2015) dan Yunitasari (2013). Dalam manajemen asma, cara untuk mencapai dan mempertahankan kontrol ditandai dengan tidak ada gejala pada siang dan malam hari, tidak ada kunjungan ke dokter/rumah sakit, kebutuhan obat pereda minim, tidak ada batasan kegiatan fisik dan olah raga, fungsi paru mendekati normal, dan tidak ada efek samping obat (Yunus, 2005).

Sebanyak 101 subjek penelitian semuanya berasal dari suku Jawa, analisis gen rs 1042713 (Arg16Gly) dan rs 1042714 (Gln27Glu) dilakukan menggunakan metode (Polymerase Chain Reaction/PCR-Restriction Fragment Length Polymorphism/RFLP). Hasil analisis memberikan kesimpulan adanya multipel polimorfisme.

Tampilan elektroforesis hasil digesti enzim NCO1 untuk gen rs 1042713 (Arg16Gly) dapat dilihat pada gambar 1. Menurut Birbian dkk. (2012) setelah mengalami amplifikasi ADRB2 mempunyai panjang 168bp. Polimorfisme Arg16Gly yang terletak pada kodon 16 dinamakan varian wildtype jika terpotong pada 146 bp dan 22 bp dari sisi 3', mutant jika terpotong pada 18 bp dari sisi 5', 22 bp dari sisi 3' dan 128 bp yang berada diantara 18 bp dan 22 bp, serta heterozygote jika 
terpotong pada 128 dan 146 bp. Pada gambar 1 menunjukkan elektroforesis hasil digesti enzim Nco1 pada rs 1042713 (Arg16Gly).

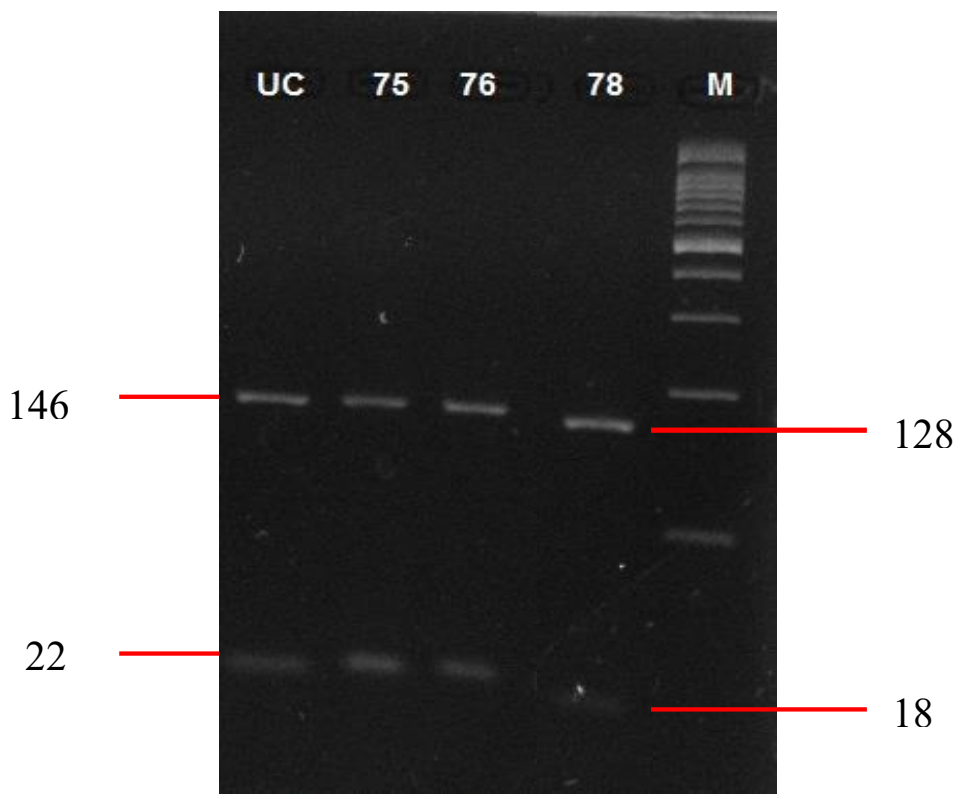

Gambar 1. Tampilan hasil elektroforesis gel agarosa 3\% hasil digesti enzim Nco1 pada rs 1042713(Arg16Gly); pada lajur 75 dan 76 terlihat fragmen 146 bp dan 22 bp (tidak terdigesti diklasifikasikan sebagai wildtype). Pada lajur 78 terlihat fragmen 128 bp dan 18 bp (terdigesti diklasifikasikan sebagai mutant).

Fragmen 168 bp produk PCR, dengan enzim Nco1 akan terpotong menjadi 18 bp, 128 bp, dan 22 bp untuk klasifikasi mutant, sedangkan pada wildtype berada pada 146 bp (tidak terpotong) dan 22 bp. Pada gambar 1, lajur 78 tidak terlihat dengan jelas pemotongan enzim Nco1 pada 22 bp, dimana ketebalan fragmen DNA akan mempengaruhi hasil foto elektroforesis.

Kriteria efektivitas ditentukan dari nilai Asthma Control Test (ACT). Skor 25 terkontrol penuh, 20-24 terkontrol sebagian, dan $\leq 19$ tidak terkontrol. Pada Tabel III diperlihatkan hubungan genotipe pada kodon 16, yaitu Arg16Gly (rs 1042713) dengan efektivitas. Hasil penelitian tidak ada pasien yang mempunyai skor ACT 25, sehingga tidak ada yang masuk kriteria terkontrol penuh.

Hasil uji statistik dengan chi square untuk mengetahui ada tidaknya hubungan antara tipe genom pada gen rs 1042713 (Arg16Gly) dengan kontrol asma menghasilkan nilai $p=0,131$. Disimpulkan tidak ada hubungan bermakna antara genotipe rs 1042713 (Arg16Gly) dengan efektivitas, sehingga tidak ada pengaruh polimorfisme gen pada rs 1042713 (Arg16Gly) terhadap efektivitas.

Tabel III. Hubungan genotipe rs 1042713 (Arg16Gly) dengan efektivitas

\begin{tabular}{lccccc}
\hline Genotipe & \multicolumn{5}{c}{ Hasil efektivitas } \\
\cline { 2 - 6 } & $\begin{array}{c}\text { Terkontrol } \\
\text { sebagian }\end{array}$ & $\begin{array}{c}\text { Tidak } \\
\text { terkontrol }\end{array}$ & $\mathrm{p}$ \\
\hline Wildtype & $\mathrm{n}$ & $\%$ & $\mathrm{n}$ & $\%$ & \\
Mutant & 20 & 27,40 & 53 & 72,60 & \\
Heterozygote & 2 & 16,67 & 10 & 83,33 & $0,131^{*}$ \\
\hline
\end{tabular}

* Menggunakan Chi Square test 
Penelitian Bleecker dkk. (2006) juga menyimpulkan tidak ada perbedaan antar tipe genom dilihat dari pengukuran arus puncak ekspirasi dan volume ekspirasi paksa. Hasil yang sama juga ditunjukkan oleh Qiu dkk. (2014), dengan pemberian salmeterol + flutikason. Penelitian yang dilakukan Soleimani dkk. (2013), pasien dengan tipe genom Arg/Arg (wildtype) menunjukkan perbaikan yang signifikan dalam parameter kontrol asma dan fungsi paru dibanding Arg/Gly (heterozigot) setelah pemberian inhaler salmeterol + flutikasone propionat. Beberapa penyebab perbedaan respon terhadap agonis $\beta 2$ aksi panjang karena perbedaan tipe genom adalah, spesifikasi bronchoprotection (Lee dkk., 2004), perbedaan ekspresi inflamasi sitokin (Shore dan Drazen., 2003), dan akhirnya berdampak pada signal dan fungsi reseptor lain yang mengontrol kontraksi saluran nafas (McGraw dkk., 2003). Selain data hubungan antara genotipe dengan efektivitas, pada Tabel III dapat dilihat persentase terkontrol sebagian pada wildtype paling besar dibanding dan mutant dan heterozygote. Hasil ini menunjukkan bahwa genotipe wildtype memberikan efektivitas lebih baik.

Untuk mengetahui pengaruh genotipe Arg16Gly terhadap efektivitas dan membandingkan efektivitas masing-masing genotipe dilakukan uji statistik yang dapat dilihat pada Tabel IV.

Tabel IV. Tabel pengaruh genotipe Arg16Gly terhadap efektivitas

\begin{tabular}{lcccc}
\hline \multicolumn{1}{c}{ Genotipe } & $\begin{array}{c}\text { Terkontrol } \\
\text { sebagian }\end{array}$ & $\begin{array}{c}\text { Tidak } \\
\text { terkontrol }\end{array}$ & $\mathrm{P}$ & $\begin{array}{c}\text { OR } \\
(95 \% \mathrm{CI})\end{array}$ \\
\hline Mutant & 2 & 10 & - & 1 \\
Wildtype & 20 & 53 & 0,43 & $1,887(0,38-9,37)$ \\
Heterozygot & 4 & 25 & 0,595 & 1,667 \\
\hline
\end{tabular}

Dari Tabel IV dapat dilihat bahwa genotipe wildtype lebih efektif dibanding mutant sebesar $1,887 x$, dan heterozygote lebih efektif 1,667x lebih besar dibanding mutant. Kesimpulan dalam penelitian ini adalah, walaupun secara statistik genotipe tidak berpengaruh terhadap efektivitas yang ditunjukkan dengan nilai $\mathrm{p}=0,131$ tetapi kemungkinan secara klinis akan memberikan efektivitas yang berbeda.

\section{KESIMPULAN}

Tidak ada hubungan bermakna antara genotipe rs 1042713 (Arg16Gly) dengan efektivitas, tetapi kemungkinan secara klinis memberikan efektivitas yang berbeda dengan urutan wildtype, heterozygote, dan mutant.

\section{UCAPAN TERIMA KASIH}

Ucapan terima kasih kepada Kemenristek Dikti untuk Hibah Doktor dan Universitas Gadjah Mada untuk Hibah Penelitian Unggulan Perguruan Tinggi (PUPT).

\section{DAFTAR PUSTAKA}

Andayani, N dan Waladi Z. 2014, Hubungan tingkat pengetahuan pasien asma dengan tingkat kontrol asma di poliklinik paru RSUD DR. Zainoel Abidin Banda Aceh. Jurnal Kedokteran Syiah Kuala, 14(3):139-45.

Birbian N, Singh J, Jindal S, dan Singia N, 2012. Association of B2-Adrenergic Receptor Polymorphisms with Asthma in a North Indian Population. Lung, 190: 497-504.

Bleecker, E.R., Yancey,S.W., Baitinger, L.A., Edwards, L.D., Klotsman, M., Anderson, W.H., dan Dorinsky, P.M, 2006, Salmeterol response is not affected by $\beta 2$-Adrenergic receptor genotype in subjects with persistent asthma, J Allergy Clin Immunol, 118(4), 809-816

Global Initiative for Asthma (GINA), 2017. Pocket Guide for Asthma Management and Prevention (for Adult and Children Older than 5 Years), diperoleh melalui situs internet: http://www.ginasthma.or. Diunduh pada tanggal 27 September 2017.

Green, S.A., Turki, J., Bejarano, P., Hall, J.P., dan Ligget, S.B., 1995, Influence of beta2-adrenergic genotypes on signal transduction in human airway smooth muscle cells. Am J Respir Cell Mol Biol, 13:25-33

Hall, IP, 2006. Pharmacogenetics. Taylor \& Francis, New York.

Hakim, L, 2012. Farmakokinetika Klinik. Bursa Ilmu, Yogyakarta. 
Haryanti, S., Ikawati, Z., Andayani, T.M, dan Mustofa, 2016, Hubungan kepatuhan menggunakan obat inhaler 32 -Agonis dan control asma pada pasien asma. Jurnal Farmasi Klinik Indonesia, 5(4), 238-248.

Israel, E., Chinchilli, V.M., Ford, J.G., Boushey, H.A., Cherniack. R., dan Craig, T.J., 2004, Use of regularly scheduled albuterol treatment in asthma: genotype-stratified, randomised, placebocontrolled cross-over trial, Lancet, 364:1505-12.

Kementrian Kesehatan RI, 2018. Riset Kesehatan Dasar Riskesdas 2018. Kemenkes RI, Jakarta

Kobilka, B., Dixon, R., Frielle, T., 1995, cDNA for the human b2-adrenergic receptor: a protein with multiple membrane-spanning domains and encoded by a gene whose chromosomal location is shared with that of the receptor for platelet-derived growth factor. Proceedings of the National Academy of Sciences of the United States of America, 84: 46-50.

Krukreti, R., Bhatnagar, P., B-Rao. C, Gupta, S., Madan, B., Das, C. Guleria, R., Athavale, A.U., Brahmachari, S.K., Ghosh, B., 2005, Beta (2)-adrenergic receptor polymorphisms and response to salbutamol among Indian asthmatic. Pharmacogenomics;6(4), 399-410.

Lee, D., Currie, G., Hall, I., Lima, J., Lipworth, B., 2004, The arginine-16 beta2-adrenoceptor polymorphism predisposes to bronchoprotective subsensitivity in patients treated with formoterol and salmeterol. Br J Clin Pharmacol, 57(1), 68-75.

Lim dan Kobzik, 2008, Sexual tension in the airways: the puzzling duality of estrogen in asthma. American Journal of Respiratory Cell and Molecular Biology, 38, 499-500

Litonjua, A.A., Gong, L., Duan, Q.L., Shin, J., Moore, M.J., Weissa, S.T., Johnsone, J.A., Kleinb, T.E., dan Altmanb, R.B., 2010, Very important pharmacogene summary ADRB2, Pharmacogenetics and Genomics, 20(1), 64-69.

Marco, R., Locatelli, F., Sunyer, J., Burney, P., 2000. Differences in incidence of reported asthma related to age in men and women. A retrospective analysis of the data of the European Respiratory Health Survey. Am J Respir Care Med, 162(1), 68-74.

McGraw, D., Almoosa K, Paul, R., Kobilka, B., Liggett, S., 2003, Antithetic regulation by adrenergic receptors of $\mathrm{G} q$ receptor signaling via phospholipase $\mathrm{C}$ underlies the airway agonist paradox, J Clin Invest, 112(4), 619-26.

Postma, D., Meyers, D., Jongepier, H., Howard, T., Koppelman, G., dan Bleecker, E., 2005, Genomewide screen for pulmonary function in 200 families ascertained for asthma. American Journal of Respiratory and Critical Care Medicine, 172, 446-452.

Price, D., Harrow, B., Small, M., Pike, J, Higgins, V., 2015, Establishing the relationship of inhaler satisfaction, treatment adherence, and patient outcomes: a prospective, real-world, crosssectional survey of US adult asthma patients and physicians. WAO J., 8(1), 26.

Qiu, Y., Zhang, D., Qin, Y., Yin, K.S., 2014, Effect of $\beta 2$-adrenergic receptor gene Arg16Gly polymorphisms on response to long-acting $\beta 2$-agonist in Chinese Han asthmatic patients. Multidisciplinary Respiratory Medicine. 22, 1-4

Rahayu, S.A., dan Hamdini, A., 2013. Hubungan tingkat kontrol asma dan kualitas hidup penderita asma yang berobat di RSUD Dr Soedarso Pontianak pada bulan Maret Sampai Mei 2012, Jurnal Fakultas Kedokteran Universitas Tanjungpura, 3(1), 3-12.

Shore, S., dan Drazen, J., 2003, Beta-agonists and asthma: too much of a good thing, Journal of Clinical Investigation, 112(4), 495-7.

Sihombing, M,. Alwi, Q., Nainggolan, O., 2010, Faktor-faktor yang berhubungan dengan penyakit asma pada usia $\geq 10$ tahun di Indonesia (Analisis data riskesdas 2007). Journal Respiratory Indonesia, 30(2), 85-91

Soleimani, F., Fahimi, F., Naghan, P.A., Nadji, S.A., Morowan, S, Naderi, N., dan Masjedi, M.R., 2013, The effect of eolymorphisms of eeta2 adrenoceptors on reponse to long-acting beta2 Agonists in Iranian asthmatic patients. Iran J Allergy Asthma Immunol, 12(4), 383-390.

Trent, R.J, Cheong, P.L., Chua, E.W., Kenned, M.A., 2013, Progresing the utilization of pharmacogenetics and pharmacogenomics into clinical care. Pathology, 45(4), 357-370.

Vrieze, A., Pstma, D.S., dan Kerstjens, H.A.M., 2003, Perimenstrual asthma: a syndrome without known cause or cure. J Allergy Clin Immunol, 112(2), 271-282 
Yunitasari A, 2013. Hubungan rinosinusitis kronik dengan tingkat kontrol asma. Tesis: Universitas Diponegoro, Semarang.

Yunus, F., 2005. The asthma control test. A new tool to improve the quality of asthma management. Proceeding of Seminar Perhimpunan Dokter Paru Indonesia, Surakarta, $1^{\text {st }}$ ed, Indah Comp, 361. 